\title{
Hospital management of intractable headaches. The Instituto de Neurologia de Curitiba approach
}

\author{
Manejo hospitalar das dores de cabeça intratáveis. Abordagem do \\ Instituto de Neurologia de Curitiba
}

\begin{abstract}
Adriel Rowe', Renato lachinski ${ }^{2}$, Vanessa Rizelio², Henry Koiti Sato², Maria Tereza de Moraes Souza Nascimento², Ricardo Krause Martinez de Souza ${ }^{2}$, Pedro André Kowacs ${ }^{2}$

'Fundação Universidade Regional de Blumenau, PR ${ }^{2}$ Serviço de Neurologia do Instituto de Neurologia de Curitiba, PR

Rowe A, lachinski R, Rizelio V, Sato HK, Nascimento MT, Souza RK, Kowacs PA Hospital management of intractable headaches. The Instituto de Neurologia de Curitiba approach.
\end{abstract}

Headache Medicine. $2011 ; 2(4): 194-9$

\begin{abstract}
Intractable headaches, also called refractory headaches, are usually unresponsive to standard therapies and comprise clinical conditions that represent a clinical management problem regarding therapy. Thereby, many approaches to manage "intractable headaches" have been proposed; meanwhile many aspects remain unclear and open to debate. Accordingly, these patients often require special care and customized management, such as inpatient treatment. Hospitalization aims to enhance management of the patients as a whole and thus improve their quality of life. This paper summarizes the Instituto de Neurologia de Curitiba (INC) approach, which comprises withdrawal of the overused medication, management of abstinence symptoms, management of rebound headache, introduction of effective prophylactic therapy, general counseling and education of the patient, and other aspects of management. The inpatient approach used at the INC is presented and a small sample of patients treated according to this approach is described and discussed.
\end{abstract}

Keywords: Intractable headaches; Refractory headaches; Inpatient treatment.

\section{RESUMO}

As dores de cabeça intratáveis, também chamadas de "cefaleias refratárias", geralmente não respondem aos tratamentos habituais e compreendem diversas clínicas as quais representam um problema de manejo terapêutico. Muitos esquemas para abordar as "dores de cabeça intratáveis" têm sido propostos, porém diversos aspectos referentes ao seu manejo permanecem obscuros e abertos ao debate. Frequentemente, estes pacientes necessitam de cuidados especiais e personalizados de tratamento, tais como o manejo hospitalar. A hospitalização visa propiciar o manejo destes pacientes de uma forma abrangente, e, assim, melhorar sua qualidade de vida. Este artigo resume a abordagem do Instituto de Neurologia de Curitiba (INC), a qual compreende a retirada da medicação em demasia, o manejo de sintomas de abstinência, o tratamento da dor de cabeça rebote, a introdução de terapia profilática eficaz, o aconselhamento geral e a educação do paciente, assim como outros aspectos envolvidos. A abordagem de internação usada no INC é apresentada e uma pequena casuística de pacientes tratados de acordo com esta abordagem é descrita e discutida.

Palavras-chave: Dores de cabeça intratáveis; Dores de cabeça refratárias; Tratamento hospitalar. 


\section{INTRODUCTION}

Intractable headaches ${ }^{(1-3)}$ (also called "refractory headaches") represent a clinical management problem regarding therapy. The problem stems from its definition: previous treatments in adequate doses have failed to control the symptoms. Table 1 summarizes a proposed classification for refractoriness of a headache to prophylactic therapy. Most patients presenting "intractable headaches" have probable chronic migraine and probable headache secondary to the overuse of excessive symptomatic medication. There are several approaches to managing "intractable headaches", some of them not tested with adequate methods. In this paper, the inpatient approach used at the Instituto de Neurologia de Curitiba (INC) for treating chronic headaches intractable to prophylactic therapy is presented and a small sample of patients treated according to this approach is described and discussed.

Table 1 - Defining intractable headache based on response to preventive treatments

\begin{tabular}{ll} 
Class & Previous response to therapy \\
\hline Class I (mild) & $\begin{array}{l}\text { Failure of adequate treatment trial of any } \\
\text { prophylactic drug }\end{array}$ \\
Class II (moderate) & $\begin{array}{l}\text { Failure of adequate treatment trials of } 2 \\
\text { prophylactic drugs }\end{array}$ \\
Class III (severe) & $\begin{array}{l}\text { Failure of adequate treatment trials of } 3 \\
\text { prophylactic drugs }\end{array}$ \\
Class IV (very severe) & $\begin{array}{l}\text { Above plus failed aggressive infusion or } \\
\text { inpatient treatment and/or failure to respond to } \\
\text { detoxification treatment in subjects with acute } \\
\text { headache pain medication overuse }\end{array}$ \\
\hline
\end{tabular}

All medications must have been used in adequate dose and duration. Failure is contingent on the headache disorder. For episodic migraine it is often defined as $<50 \%$ reduction in frequency of headache days or attacks. For chronic migraine, treatment failure is defined as $<30 \%$ reduction in headache days. Headache day is defined as at least 4 hours of continuous pain with a peak intensity that is at least of moderate severity (abridged from Silberstein et al. Headache 2010;50:1499-1506.3)

\section{THE INC APPROACH}

The INC approach combines several lines of therapy, to know: a) withdrawal of the overused medication, b) management of the abstinence symptoms, c) management of rebound headache, d) introduction of effective prophylactic therapy, e) general counseling and education of the patient, d) other aspects of management. All these aspects of management are not new and will be discussed below. Although the items $a, b$ and $c$ are usually coined as "bridge therapy", we prefer the expression "transitional therapy", akin to its use for the treatment of cluster headache.

\section{TRANSITIONAL THERAPY}

\section{Withdrawal of the medication overused}

Medication previously overused is withdrawn abruptly $y^{(4-7)}$ and is never administered again during hospitalization.

\section{Management of the abstinence symptoms}

Abstinence symptoms are managed accordingly to their occurrence. Nausea is managed either with metoclopramide or with bromopride. Previously to their prescription, the staff performs a detailed anamnesis directed towards detecting previous adverse events to these compounds such as somnolence, akathisia and/ or other extrapyramidal reactions. ${ }^{(8)}$ If some of these symptoms are detected, preference is given for domperidone, trimebutine, ondasentron or similar drugs. (9) Insomnia is usually managed with a benzodiazepine such as midazolam. Anxiety might be treated with other benzodiazepines such as alprazolam, cloxazolam, and bromazepam. Risperidone or quetiapine might be prescribed instead, in case of extreme anxiety or in case bipolar disorder is associated or suspected. ${ }^{(10,11)}$ A sensitive point is hydration. ${ }^{(4)}$ It is important to remind that these patients may present with vomiting, become drowsy and lessen their water intake. In this setting, if drugs that may lead to hypotension such as chlorpromazine are needed, vigorous hydration with saline is desired, unless in the case of a clear contraindication such as heart failure or uncontrolled hypertension.

\section{Management of rebound headache}

Although rebound headache is considered to be an abstinence symptom, it will be considered separately due to its complexity. The first step used in the INC is to place the patient on an intravenous NSAID, usually ketoprofen 100 mg t.i.d. ${ }^{(12)}$ - an approach avoided if the overused medication was ketoprofen or another NSAID. Besides ketoprofen, intravenous chlorpromazine is given, ${ }^{(4,13)}$ except for patients bearing a low systolic blood pressure or bringing a history of intolerance to chlorpromazine or to other dopamine receptor antagonist. Chlorpromazine may be given at doses ranging from $0.2 \mathrm{mg} / \mathrm{kg}$ up to $0.7 \mathrm{mg} / \mathrm{kg} .{ }^{(13)}$ Although some authors advocate it to be given in bolus, we prefer to dilute it in $100 \mathrm{ml}$ of saline 
and infuse it in about 30-60 minutes. We start with a fixed dose of $25 \mathrm{mg}+100 \mathrm{ml}$ of saline, stopping infusion whenever headache is controlled. The dose is gradually increased if this does not happen. It is important to remember that adverse effects like nasal congestion, mild akathisia and severe hypotension may occur. ${ }^{(13)}$ While nasal congestion and mild akathisia may be cumbersome, orthostatic hypotension may be severe, thus both the nursing staff and the patient must be warned that he should avoid standing and walking unattended. As reported by Monzillo et al., haloperidol may be given as well. ${ }^{(14)}$ Metamizole (dipyrone) is not used frequently at the INC emergency room, but 1 gram intravenously is reported to be effective. ${ }^{(15)}$ Metamizole potential to cause hypotension must be also kept in mind, and respective care should be taken. Until the year of 2010 we used intravenous dihydroergotamine (DHE), ${ }^{(4)}$ except for those patients overusing ergots or with cardiovascular disorders or risk factors. About 30 minutes prior to the administration of $\mathrm{DHE}$, we used to prescribe an intravenous antiemetic. DHE was given in the dose of $0.5 \mathrm{mg}$ diluted in $50 \mathrm{ml}$ of isotonic saline, given in 30 minutes or until the resolution of pain. Unfortunately, the lack of registration on the local regulatory board (ANVISA) halted the administration of DHE. Resort to the use of propofol is our last therapeutic frontier. ${ }^{(16)}$ Propofol is quite easy to administer, but great attention must be paid in case of previous administration of chlorpromazine or another sedating drug. Before starting propofol infusion, even the most experienced physician should take care to have the resuscitating material close by. ${ }^{(16)}$ Administration should start with a bolus injection of $3 \mathrm{mg}$, followed by sequential injections of $2 \mathrm{mg}$, always letting the patient to regain consciousness before the administration of the next dose. If there is any improvement, doses are given repeatedly up to a total dose of $300 \mathrm{mg}$. However, if the patient headache fails to improve in the first three doses, the procedure is stopped. (16) Several trials have failed to show steroids as an effective transitional therapy or in solving rebound headache. ${ }^{(6,17)}$ However, in selected cases especially those in which other approaches have failed, the administration of steroids should be considered as an option. ${ }^{(5,6)}$ Responders must be warned about the dangers of prolonged use of steroids, since steroid dependence may occur.

\section{Introduction of effective prophylactic therapy}

Patients that seek for hospital management of their chronic and refractory headaches usually have been submitted previously to several prophylactic therapies. That is why a detailed past medication history is a key point in choosing the prophylactic drug to be introduced. Not only the kind of medication previously used, but also its dosage, efficacy and tolerability must be surveyed to draw a clear picture of the patient's background. The prophylactic drug usually introduced is methysergide, a drug with a strong effect on $5 \mathrm{HT} 2 \mathrm{~A}, 5 \mathrm{HT} 2 \mathrm{~B}$ and $5 \mathrm{HT} 2 \mathrm{C}$ receptors. ${ }^{(18)}$ Methysergide has a clear-cut advantage of an early prophylactic effect, and has also been strongly recommended in the literature for the treatment of resistant cases of migraine with a high attack frequency. ${ }^{(18)}$ But it is never enough to remind that, as methysergide has some vasoconstrictive effect, the prescriber must exert great caution - or even avoid - recommending other vasoconstrictive drugs such as ergotics or triptans. Another key point is that methysergide prescription should follow the rule "start low, go slow", usually beginning at $1 \mathrm{mg}$ at bedtime and increasing the dose at $1 \mathrm{mg}$ a day until $1 \mathrm{mg}$ tid or $2 \mathrm{mg}$ bid. Among other traditional migraine prophylactic drugs, one most formally tested for chronic migraine is topiramate. However, topiramate prophylactic effect may take longer to ensue..$^{(5,19,20)}$ Valproate is another useful prophylactic drug, especially for patients with concomitant bipolar disorder, in whom the daily dose must be raised above the usual $1 \mathrm{~g} /$ day. ${ }^{(21)}$ As betablockers, amitriptyline is a useful migraine prophylactic drug $^{(22)}$ and was also shown to be effective for chronic tension-type headache. ${ }^{(23)}$ Patients responding to intravenous chlorpromazine may be switched to oral chlorpromazine. Chlorpromazine may be useful in anxious patients, in those presenting with manic symptoms or with a family history of psychiatric disorders. ${ }^{(13)}$ Most chronic headache patients have used several prophylactic drugs and associations of them. Choice of the prophylactics to be introduced during hospitalization and at the time of hospital discharge involve several, factors, such as efficacy, tolerability, previous response, and the combination of different mechanisms of action. ${ }^{(24)}$

\section{General counseling and education of the patient}

Further than just giving medicines to the refractory headache patient, the hospitalization is an excellent opportunity for counseling the patient against medication overuse behavior and to detect and treat anticipatory anxiety. ${ }^{(25)}$ Patients are advised for aerobic physical activity. ${ }^{(25-27)}$ Patients are also advised to promote changes 
in their lifestyle, if deemed necessary, and taught to have realistic expectations regarding their headache control, which may not be absolute.

\section{Other aspects of management}

Other therapeutic approaches can be undertaken according to the patients needs. Rheumatologic, psychiatric or psychological consultations are asked for when needed. ${ }^{(25,28)}$ If deemed appropriate, biofeedback sessions are prescribed. $(25,29,30)$

\section{SERIES PRESENTATION}

We retrospectively gathered data from the INC hospital files dated from 2006 to 2007. Nineteen records were retrieved. Of these, 18 were female and one male. Fiffeen suffered from chronic migraine or probable chronic migraine - since associated medication-overuse headache was not ruled out-, one from post craniotomy headache and one from sustained hydrocephalus-related headache. Most patients had associated probable medicationoveruse headache and all had a class II or a class III intractability to prophylactic therapy. ${ }^{(3,31)}$ Regarding comorbidities and associated conditions, one suffered from somatoform disorder, two from major depression, four from bipolar mood disorder and two from generalized anxiety, as diagnosed either by the consulting psychiatrist or by the neurologist in charge based in the DSM-IV criteria. Most of the patients were using multiple prophylactic drugs. As an example, 17 of the patients were using two or more preventive drugs. Intravenous dihydroergotamine was given for 17 of the 19 patients, usually in a tid. dose regimen or as needed, for periods ranging from one to 12 days. Thirteen of the patients responded completely to dihydroergotamine, one had a partial response and three did not respond at all. Four patients needed intravenous propofol, and all of them were responders. Methysergide was given for eight of the 19 patients.

\begin{tabular}{|c|c|c|c|c|}
\hline \multirow{2}{*}{$\begin{array}{l}\text { Patient } \\
\text { \#1 }\end{array}$} & \multirow{2}{*}{$\begin{array}{l}\text { Age/ } \\
\text { Gender } \\
34 / F\end{array}$} & \multirow{2}{*}{$\begin{array}{l}\text { Diagnosis } \\
\text { pCM/pMOH, major depression }\end{array}$} & \multicolumn{2}{|c|}{$\begin{array}{l}\text { Prophylaxis at the admission in Hospital } \\
\text { Headache Control }\end{array}$} \\
\hline & & & AMT & i.v. CPZ, i.v. DHE, VPA \\
\hline \#2 & $48 / F$ & $\mathrm{pCM} / \mathrm{pMOH}$ & TPM & i.v. CPZ, i.v. DHE, VPA \\
\hline \#3 & $22 / \mathrm{F}$ & $\begin{array}{l}\mathrm{pCM} / \mathrm{pMOH} / \text { bipolar disorder/ } \\
\text { omatoform disorder }\end{array}$ & TPM,AMT, VPA, CPZ & i.v. DHE, PPF, MET \\
\hline$\# 4$ & $37 / F$ & Post craniotomy headache/pMOH & CPZ, AMT & PPF, GPT \\
\hline \#5 & $51 / F$ & $\begin{array}{l}\text { Unclassified chronic headache, } \\
\text { pMOH, bipolar disorder }\end{array}$ & AMT, VPA & PPF, TPM \\
\hline \#6 & $42 / F$ & pCM & TPM, ATL & i.v. DHE, MET \\
\hline$\# 7$ & $35 / \mathrm{M}$ & CTTH, major depression & AMT, TZ & PPF, VPA \\
\hline \#8 & $32 / F$ & $\mathrm{pCM}$ & VPA, FLN & i.v. CPZ, i.v. DHE, MET \\
\hline \#9 & $44 / F$ & $\mathrm{pCM} / \mathrm{pMOH}$, bipolar disorder & AMT, VPA, FLN & i.v. $\mathrm{DHE}, \mathrm{MET}$ \\
\hline$\# 10$ & $41 / F$ & $\mathrm{pCM} / \mathrm{pMOH}$ & ATL, AMT & i.v. DHE, MET \\
\hline$\# 11$ & $29 / F$ & $\begin{array}{l}\text { Unclassified chronic headache/ } \\
\text { pMOH/arrested hydrocephalus }\end{array}$ & $\mathrm{AMT}, \mathrm{CPZ}$ & i.v. DHE, TPM \\
\hline \#12 & $36 / F$ & $\mathrm{pCM} / \mathrm{pMOH}$ & AMT, TPM & i.v. DHE, MET \\
\hline \#13 & $21 / F$ & $\mathrm{pCM} / \mathrm{pMOH}$, generalized anxiety & PPN, FLN & i.v. DHE, TPM, MET \\
\hline \#14 & $32 / F$ & $\mathrm{pCM} / \mathrm{pMOH}$, generalized anxiety & ATL, FLN & i.v. CPZ, i.v. DHE, TPM \\
\hline \#15 & $43 / F$ & $\mathrm{pCM} / \mathrm{pMOH}$, bipolar disorder & TPM, VPA & i.v. $\mathrm{CPZ}$, i.v. $\mathrm{DHE}$ \\
\hline \#16 & $29 / F$ & $\mathrm{pCM} / \mathrm{pMOH}$ & TPM, MET & i.v. $C P Z$, i.v. $D H E, C P Z$ \\
\hline$\# 17$ & $32 / F$ & $\mathrm{pCM} / \mathrm{pMOH}$ & TPM, VPA, FLN & i.v. $\mathrm{DHE}, \mathrm{MET}$ \\
\hline \#18 & $41 / F$ & $\mathrm{pCM} / \mathrm{pMOH}$ & ATL, AMT & i.v. $\mathrm{DHE}, \mathrm{MET}$ \\
\hline \#19 & $55 / F$ & $\mathrm{CM} / \mathrm{pMOH}$ & VPA, MET & i.v. $C P Z$, i.v. DHE, $\square$ VPA \\
\hline
\end{tabular}

F: female; M: male; pCM: probable chronic migraine; $\mathrm{pMOH}$ : probable medication overuse headache; CTTH: chronic tension-type headache; AMT: amitriptyline; TPM: topiramate; VPA: sodium valproate/divalproate; CPZ: chlorpromazine; ATL: atenolol; TZ: tizanidine; FLN: flunarizine; MET: methysergide; DHE: dihydroergotamine; PPF: propofol; i.v.: intravenous; : $\square$ increase 


\section{DISCUSSION}

Hospitalization aims to control or to reduce the intractable headache, to restore functionality to the patients by reducing the incapacity, and to treat the associated comorbidities, thus improving the patients' quality of life. While abrupt withdrawal of the medication overused is perhaps the greater unanimity in the management of refractory chronic headaches associated with medication overuse, all the other aspects are open to challenge and debate. Aspects regarding management of analgesics abstinence symptoms and rebound headache, transitional (bridge) therapy, timing and type of prophylaxis are all less clear and amenable to be challenged. (32) The aggressive analgesic/antimigraine approach that we have described probably would not be enough without the concomitant changes in prophylactic therapy. Even the issue of hospitalization is not a consensus. ${ }^{(25)}$ Although it is still possible in Brazil, in many countries it has been substituted by day-hospital approaches, because of lack of acceptance by the insurers. From the scientific standpoint, hospitalization is not associated with better outcomes in the management of chronic headaches regarding withdrawal of the overused drug or adherence to prophylactic therapy. ${ }^{(32)}$ As advantages we list a better monitoring of the drug withdrawal at its first days, earlier rescue therapy for rebound headache and optimal facilities for continuous medication and/or procedures needing to be monitored. (32) Besides, taking the patient away from its environment is an excellent opportunity for reviewing all the aspects exposed above, and it allows a comprehensive approach. Since patients to be hospitalized usually belong to a more complex group of patients, they frequently have associated fibromyalgia, psychiatric symptoms and/or sleep disorders. ${ }^{(25)}$ As posed before, psychiatric consultation, or rheumatologic consultation as well, may enhance patient care as a whole. Saper et a| ${ }^{(28)}$ and Freitag et $\mathrm{al}^{(25)}$ also share this view in favor of using hospitalization to treat these patients. As there are no rules that fit all patients, each patient must be individually evaluated and his/her physician must weight the decision about how and where to treat him/her. Although the series presented in this paper is merely illustrative and did not aimed to justify the approach, it gives an idea of the profile of the patients that were submitted to this approach at our neurology service. Based in the arguments above-mentioned, the INC staff feels quite well acquainted in using the inpatient approach for treating complex chronic headache and/or intractable headache patients. However, unexpected pitfalls may impair the INC's approach such as the recent repetitive shortages on the supply of methysergide and the comments about the supplier's discontinuation of the sale of this prophylactic medication.

\section{REFERENCES}

1. Valença MM, Valença LPAA, Bordini C, Farias da Silva W, Speciali JG. Cefaléia de "difícil controle". Migrâneas cefaléias. 2003; 6:1 $17-20$

2. Goadsby PJ, Schoenen J, Ferrari MD, Silberstein SD, Dodick D. Towards a definition of refractory headache for use in clinical practice and trials. Cephalalgia. 2006;26(9): 1 168-70. Comment in Cephalalgia. 2007;27(7):858-9; author reply 859.

3. Silberstein SD, Dodick DW, Pearlman S. Defining the pharmacologically intractable headache for clinical trials and clinical practice. Headache. 2010;50(9): 1499-506.

4. Paemeleire K, Crevits L, Goadsby PJ, Kaube H. Practical management of medication-overuse headache. Acta Neurol Belg. 2006;106(2):43-51.

5. Katsarava Z, Holle D, Diener HC. Medication overuse headache. Curr Neurol Neurosci Rep. 2009;9(2):115-9.

6. Pageler L, Katsarava Z, Diener HC, Limmroth V. Prednisone vs placebo in withdrawal therapy following medication overuse headache. Cephalalgia. 2008;28(2):152-6. Comment in: Cephalalgia. 2008;28(9):999-1000; author reply 1000.

7. Zeeberg P, Olesen J, Jensen R. Discontinuation of medication overuse in headache patients: recovery of therapeutic responsiveness. Cephalalgia. 2006;26(10):1192-8.

8. Patanwala AE, Amini R, Hays DP, Rosen P. Antiemetic therapy for nausea and vomiting in the emergency department. J Emerg Med. 2010;39(3):330-6.

9. Krymchantowski AV, Filho PF, Bigal ME. Rizatriptan vs. rizatriptan plus trimebutine for the acute treatment of migraine: a doubleblind, randomized, cross-over, placebo-controlled study. Cephalalgia. 2006;26(7):871-4.

10. Dusitanond P, Young WB. Neuroleptics and migraine. Cent Nerv Syst Agents Med Chem. 2009;9(1):63-70.

11. Krymchantowski AV, Jevoux C, Moreira PF. An open pilot study assessing the benefits of quetiapine for the prevention of migraine refractory to the combination of atenolol, nortriptyline, and flunarizine. Pain Med. 2010;1 1(1):48-52.

12. Karabetsos A, Karachalios G, Bourlinou P, Reppa A, Koutri R, Fotiadou A. Ketoprofen versus paracetamol in the treatment of acute migraine. Headache. 1997;37(1):12-4.

13. Lane RL, Ross R. Intravenous chlorpromazine - Preliminary results in acute migraine. Headache. 1985;25(6):302-4.

14. Monzillo PH, Nemoto PH, Costa AR, Sanvito WL. Acute treatment of migraine in emergency room: comparative study between dexametasone and haloperidol. Preliminary results. Arq Neuropsiquiatr. 2004;62(2B):513-8. [Article in Portuguese].

15. Bigal ME, Bordini CA, Speciali JG. Intravenous metamizol (dipyrone) in acute migraine treatment and in episodic tensiontype headache--a placebo-controlled study. Cephalalgia. $2001 ; 21(2): 90-5$. 
16. Mendes PM, Silberstein SD, Young WB, Rozen TD, Paolone MF. Intravenous propofol in the treatment of refractory headache. Headache. 2002;42(7):638-41.

17. Bøe MG, Mygland A, Salvesen R. Prednisolone does not reduce withdrawal headache: A randomized, double-blind study. Neurology 2007;69(1):26-31. Comment in: Neurology. 2007;69(1):14-5. Neurology. 2008;70(6):491; author reply 491.

18. Silberstein SD. Methysergide. Cephalalgia. 1998;18(7):421-35.

19. Mei D, Ferraro D, Zelano G, Capuano A, Vollono C, Gabriele $C$, et al. Topiramate and triptans revert chronic migraine with medication overuse to episodic migraine. Clin Neuropharmacol. 2006;29(5):269-75.

20. Diener HC, Bussone G, Van Oene JC, Lahaye M, Schwalen S, Goadsby PJ; TOPMAT-MIG-201 (TOP-CHROME) Study Group. Topiramate reduces headache days in chronic migraine: a randomized, double-blind, placebo-controlled study. Cephalalgia. 2007;27(7):814-23

21. Mathew NT, Ali S. Valproate in the treatment of persistent chronic daily headache. An open label study. Headache. 1991; $31(2): 71-4$

22. Silberstein SD. Preventive migraine treatment. Neurol Clin. $2009 ; 27(2): 429-43$

23. Torrente Castells E, Vázquez Delgado E, Gay Escoda C. Use of amitriptyline for the treatment of chronic tension-type headache. Review of the literature. Med Oral Patol Oral Cir Bucal. 2008; 13(9):E567-72.

24. Krymchantowski AV, Bigal ME. Polytherapy in the preventive and acute treatment of migraine: fundamentals for changing the approach. Expert Rev Neurother. 2006;6(3):283-9.

25. Freitag FG, Lake A 3rd, Lipton R, Cady R, Diamond S, Silberstein S; US Headache Guidelines Consortium, Section on Inpatient Treatment Chairpersons. Inpatient treatment of headache: an evidence-based assessment. Headache. 2004 ;44(4):342-60.

26. Queiroz LP, Peres MF, Kowacs F, Piovesan EJ, Ciciarelli MC, Souza JA, Zukerman E. Chronic daily headache in Brazil: a nationwide population-based study. Cephalalgia. 2008;28 (12):1264-9.
27. Seok JI, Cho HI, Chung CS. From transformed migraine to episodic migraine: reversion factors. Headache. 2006;46 (7): $1186-90$.

28. Saper JR, Lake AE 3rd, Madden SF, Kreeger C. Comprehensive/ Tertiary care for headache: a 6-month outcome study. Headache. 1999;39(4):249-63

29. Holroyd KA, Penzien DB. Pharmacological versus nonpharmacological prophylaxis of recurrent migraine headache: a meta-analytic review of clinical trials. Pain. 1990;42(1):1-13.

30. Penzien DB, Rains JC, Lipchik GL, Creer TL. Behaviora interventions for tension-type headache: overview of current therapies and recommendation for a self-management model for chronic headache. Curr Pain Headache Rep. 2004;8(6): 489-99.

31. Headache Classification Subcommittee of the International Headache Society. The International Classification of Headache Disorders, 2nd ed. Cephalalgia. 2004; 24 (Suppl 1): 1-160.

32. Rossi P, Jensen R, Nappi G, Allena M; COMOESTAS Consortium. A narrative review on the management of medication overuse headache: the steep road from experience to evidence. J Headache Pain. 2009;10(6):407-17.

Received: 9/8/2011

Accepted: 12/3/2011 